\title{
Carcass characteristics of rabbits fed different forages as supplement
}

Ibrahim, $\mathrm{H}$.

Department of Animal Production, Faculty of Agriculture, Ibrahim Badamasi Babangida University, Lapai, Niger State, Nigeria. Corresponding author: ihadiza080@gmail.com; 08036101761

\section{Abstract}

The experiment was carried out to determine the carcass characteristics of weaned rabbits fed selected forages as feed supplement. A total number of thirty-six (36) weaned mixed breed of rabbits were allotted randomly to four (4) treatments with nine (9) rabbits per treatment and further replicated three (3) times with three rabbit per replicate and designated as Control (T1) concentrate plus (+) Amaranthus, (T2) concentrate plus (+) tridax, (T3) concentrate plus (+) fig leaves, (T4) concentrate plus (+) water melon waste. The experiment lasted for eight (8) weeks. Data were generated on carcass characteristics, internal organs, by-products. Results obtained revealed that the value of carcass traits, internal organs and by-products were not significantly $(P>0.05)$ different for all the parameters obtained except for liver and lungs (internal organs), pelts (skin) and hind legs (by-products). Based on the findings, it can be concluded that T1 (concentrate plus Amaranthus), was better than other treatment groups and therefore can be used as supplement to concentratefeed.

Keywords: Rabbits, supplements, carcass, characteristics, forages

\section{Introduction}

Over the years, the world population has witnessed a drastic increase in human population especially in developing countries like Nigeria. Odunsi (2003) reported that the rapid growth of human and livestock population is creating an increase in the requirements for food and feed in less developed countries. This has led to an increased demand for food and protein of animal origin which is in short supply. FAO (2006) estimated the average protein consumption in Nigeria to stand at $8 \mathrm{~g} /$ capita/day which is in sharp contrast to $38 \mathrm{~g} / \mathrm{capita} /$ day recommended for an individual per day (FAO, 2006). Protein is required by humans and animals for body tissue repair, body maintenance, optimal growth and development therefore insufficient protein intake especially in developing countries like Nigeria has led to poor growth, poor mental development as well as high infant mortality (Adama,2007). In order to bridge this gap, necessary and practical initiatives are required (Abu et al., 2008). One of such initiatives is the use of micro livestock like rabbit which are unconventional protein source (Adesope, 2000). Feeding account for about $70 \%$ total cost of production (Aduku and Olokoji, 1990). Hence the use of unconventional feedstuff is gaining ground in many developing countries and Nigeria in particular. The reduction of cost using cheap and unconventional feed materials is an important aspect of commercial rabbit production (Muriu et al. 2002). Rabbits are classified as pseudo ruminants due their ability to eat forages and digest fibre efficiently. They can depend on forage alone although concentrate improves the weight gain. The National Research Council (NRC, 1981) reported that rabbits utilize green feeds and that in ideal condition they grow so rapidly that their rate of gain is slightly lower than that of broiler chickens. They (rabbits) like more leafy and succulent greens more than the 


\section{Carcass characteristics of rabbits fed different forages as supplement}

non-succulent and woody plants. When allowed to select their own diet in a natural habitat, rabbits select the most tender, succulent plant parts or the plant parts that are most nutrient dense and lowest in available cell walls. Some researchers refer to animals that practice this type of eating behaviour as concentrate selectors, a practice that allows the animal to meet the dietary requirements for their high metabolic rate (Cheeke, 1994). Rabbits have high feed intake $(65-80 \mathrm{~g} / \mathrm{kg}$ body weight) and fast feed transit time (19 hours), which enable them to consume lower quality forages and still meet their nutritional need (Gidenne, 1992). This research work is aimed at evaluating the effects of different forage wastes as supplement on the carcass characteristics of rabbit meat.

\section{Materials and methods \\ Location of the experiment}

The research work was carried out at the Rabbit Section of the Teaching and Research Farm of Ibrahim Badamosi Babangida Lapai, Niger state. Lapai lies between latitude $9.31^{\circ}$ and $9.45^{\circ}$, east of the equator and is very close to Minna, the state capital (Usman, 2011).

\section{Source of rabbits and test ingredient}

The thirty-six weaned rabbits of mixed sexes and breeds were obtained from Sultan Veterinary Consult farm No 2, Samaru Street hayindogo Samaru Zaria, Kaduna state. Different forage wastes as Tridax procumbens, Amaranthus waste, fig leaves, and water melon waste were collected from the surrounding environment in Lapai town, Lapai Local Government Area of Niger state, Nigeria. They were washed with salt solution prior to feeding the animals while premix, salt, lime stone and salt were obtained from Minna.

\section{Experimental diets and management of rabbits}

Thirty-six weaned rabbits mixed breeds and sexes, age between 5-6 weeks were randomly allocated to four treatment groups with nine rabbits per treatment. Each treatment had three replicates of three rabbits per replicate. The same experimental diet was formulated with crude protein set at $23 \%$ for each. T1 was designated as concentrate with Amarathus, T2 concentrate and Tridax procumbens waste, T3 concentrate with fig leaves waste and $\mathrm{T} 4$ concentrate and water melon peels. The rabbits were giving Ivomatine injection against both endo and ectoparasite. Vitacox-plus and Neo-furaserylplus were adequately given as well. The cages were well clean disinfected with Dettol and equipped with drinkers and feeders. Prior to the experiment, the animals were fed concentrate and allowed the adjustment period of one week to enable the animals get used to their various cages and diets. Fresh clean water was provided ad-libitum and the forages were measured before giving throughout the research period. The experiment lasted for 8 weeks.

Table 1: Composition of Experimental Diets

\begin{tabular}{lllll}
\hline Ingredients & $\mathrm{T}_{1:}$ & $\mathrm{T}_{2:}$ & $\mathrm{T}_{3:}$ & $\mathrm{T}_{4:}$ \\
\hline Maize & 76.00 & 76.00 & 76.00 & 76.00 \\
Fish meal & 1.50 & 1.50 & 1.50 & 1.50 \\
Groundnut cake & 20.00 & 20.00 & 20.00 & 20.00 \\
Limestone & 1.00 & 1.00 & 1.00 & 1.00 \\
Bone meal & 1.00 & 1.00 & 1.00 & 1.00 \\
Salt & 0.25 & 0.25 & 0.25 & 0.25 \\
Premix & 0.25 & 0.25 & 0.25 & 0.25 \\
Total & 100 & 100 & 100 & 100 \\
Key & & & \\
$\mathbf{T}_{\mathbf{T}}=$ Concentrate plus Ammarathus (100g) & \multicolumn{2}{c}{$\mathbf{T}_{3}=$ Concentrate plus Fig leaves (ficus Carpensis) (100g) } \\
$\mathbf{T}_{2}=$ Concentrate plus Tridax procumbens (100g) & \multicolumn{2}{c}{$\mathbf{T}_{4}=$ Concentrate plus Water Melon Waste (100g) } \\
& & $\mathbf{9 7}$ &
\end{tabular}




\section{Ibrahim}

\section{Data collection}

Carcass analysis

A total of eight rabbits were selected from the experimental animals and used for the carcass analysis. The animals reflecting the average weight of the group were selected from the three replicates for carcass yield and organ characteristics evaluation. The final live weights of the randomly selected rabbits were recorded after the animals were fasted overnight prior to slaughtering. They were tagged individually for proper identification and recording. The rabbits were slaughtered by severing their jugular vein and carotid artery at the atlas vertebra. The rabbits were hung head downward for 10 minutes to allow for proper bleeding. The carcasses were dressed by removing the pelts and were decapitated at the atlantaoccipital joint. The hind feet were cut along the joint between the tibia calcaneous while the fore feet were cut at the carpal region and the tails were removed close to the base. All the parts were weighed individually and expressed as the percentage of live weight. The organs (heart, liver, kidneys, lungs, spleen) were also weighed and expressed as percentage of live weight as prescribed by Awosanya (1989). The live weights of the rabbits were obtained before slaughter using a weighing scale.

\section{Slaughter weight (g)}

After slaughtering, the rabbits were allowed to bleed properly and completely. Their weights were taken prior to and after slaughter and recorded. The blood loss weight was calculated using the formula as blood loss = live weight - slaughter weight .

\section{Eviscerated weight (g)}

The external and internal organs of the rabbits were all removed and the remaining carcasses were weighed as the eviscerated weight.

\section{Dressing percentage (\%)}

Dressing percentage was obtained using the formula below:
Dressing percentage $=$

Eviscerated weight $\quad$ X 100

Live weight (g)

(Biya et al., 2003)

\section{Data analysis}

The data generated were subjected to Analysis of Variance (ANOVA) using statistical package for social sciences (SPSS, 1998). The means were separated using Duncan Multiple Range Test (DMRT) as described by Duncan (1955).

\section{Results and discussion}

The mean value of the carcass traits of rabbit fed different forages as supplement are shown in Table 2. There were no significant $(\mathrm{P}<0.05)$ differences in the parameters measured except for the dressing weight expressed as percentage live weight. The result was not in agreement with the observation by Taiwo et al. (2014) and Naandam et al. (2012) in rabbits fed stylothensis and sidaacuta as sole feed.

Internal organs (liver, kidney, lungs, intestine, heart and caecum) of rabbits fed different forages as supplements are presented in Table 3. There were no significant $(p>0.05)$ differences in all the parameters considered. The result aligned with the findings of Esiegwu et al. (2013) that Garcina kola seed meal had no influence on internal organs weight of rabbits, but disagreed with Naandam et al. (2012), where gut characteristics in rabbits were affected by types of forages used. The result of by-products (Blood weight, Pelt/skin, Head weight, Tail weight, Fore leg and Hind leg) of rabbits fed different forages as supplements are presented in Table 4 . There were no significant $(p>0.05)$ differences in the parameters determined except for pelt/skin and hind leg weight. This could probably suggest that the dietary treatments result in negative metabolic reactions or disorders that could affect muscles growth, lipogenesis / lipolysis or 


\section{Carcass characteristics of rabbits fed different forages as supplement}

osteolastic activity. (Taylor et al., 2003). Moreover, Aduku et al. (1986) reported that skin, feet and some offals are not consumed in Europe and U.S.A; they only increased the dressing percentages of rabbit from 6062 and $50 \%$, respectively.

Table 2: Carcass characteristics of rabbits fed different forages as supplements

\begin{tabular}{lllllll}
\hline Parameters & T1 & T2 & T3 & T4 & SED & LSD \\
\hline Thoracic (\%Lw) & 46.20 & 47.13 & 49.93 & 38.63 & 6.98 & NS \\
Fore limb (\%Lw) & 42.93 & 43.53 & 42.30 & 41.10 & 6.41 & NS \\
Hind limb (\%Lw) & 86.97 & 91.57 & 76.60 & 62.66 & 13.12 & NS \\
Dressing wt. (\%Lw) & 533.33 & $501.67^{\mathrm{b}}$ & $533.33^{\mathrm{b}}$ & $500.00^{\mathrm{b}}$ & 84.16 & $*$ \\
Slaughter wt. (g) & 1066.67 & 1156.67 & 1050.00 & 1033.33 & 128.6 & $\mathrm{NS}$ \\
Lumber sacral (\%Lw) & 102.47 & 110.60 & 106.13 & 94.07 & 18.62 & $\mathrm{NS}$ \\
Neck weight (\%Lw) & 13.40 & 15.27 & 15.47 & 13.00 & 3.51 & $\mathrm{NS}$ \\
\hline
\end{tabular}

$\mathrm{abc}=$ means within the same row bearing different superscript differ significantly $(\mathrm{p}<0.05) \quad \mathrm{NS}=$ not significant difference $(\mathrm{P}>0.05) *=$ significant $(\mathrm{P}<0.05) \mathrm{SEM}=$ standard error of means. least significant difference (LSD) Key: $\mathrm{T}_{1}=$ Concentrate plus Ammarathus $(100 \mathrm{~g}) ; \mathrm{T}_{2}=$ Concentrate plus Tridax procumbens $(100 \mathrm{~g}) ; \mathrm{T}_{3}=$ Concentrate plus Fig leaves (ficus carpensis) $(100 \mathrm{~g}) ; \mathrm{T}_{4}=$ Concentrate plus Water Melon Waste $(100 \mathrm{~g})$

Table 3: Internal organs of rabbits fed different forages as supplements

\begin{tabular}{lllllll}
\hline Parameters & T1 & T2 & T3 & T4 & SED & LSD \\
\hline Liver & 15.87 & 17.23 & 15.13 & 13.20 & 1.04 & NS \\
Kidney & 4.70 & 5.47 & 4.70 & 4.33 & 0.29 & NS \\
Lungs & 3.53 & 3.97 & 4.70 & 2.80 & 0.240 & NS \\
Intestine & 79.80 & 82.07 & 71.60 & 80.87 & 5.69 & NS \\
Heart & 1.73 & 1.90 & 1.43 & 1.27 & 0.10 & NS \\
Caecum & 26.53 & 32.07 & 29.87 & 34.30 & 2.11 & NS \\
\hline
\end{tabular}

$\mathrm{abc}=$ means within the same row bearing different superscript differ significantly $(\mathrm{p}<0.05) \quad \mathrm{NS}=$ not significant difference $(\mathrm{P}>0.05) *=$ significant $(\mathrm{P}<0.05) \mathrm{SEM}=$ standard error of means. least significant difference (LSD)

Key: $\mathrm{T}_{1}=$ Concentrate plus Ammarathus $(100 \mathrm{~g}) ; \mathrm{T}_{2}=$ Concentrate plus Tridax procumbens $(100 \mathrm{~g}) ; \mathrm{T}_{3}=$ Concentrate plus Fig leaves (ficus carpensis) $(100 \mathrm{~g}) ; \mathrm{T}_{4}=$ Concentrate plus Water Melon Waste $(100 \mathrm{~g})$

Table4: Table 4: By -products of rabbits fed different forages as supplements

\begin{tabular}{llllllr}
\hline $\begin{array}{l}\text { Parameters } \\
\text { \% live weight }\end{array}$ & $\mathbf{T}_{\mathbf{1}}$ & $\mathbf{T}_{\mathbf{2}}$ & $\mathbf{T}_{\mathbf{3}}$ & $\mathbf{T}_{\mathbf{4}}$ & $\mathbf{S E M}$ & LSD \\
\hline Blood weight & 16.47 & 15.33 & 16.20 & 14.33 & 1.44 & $\mathrm{NS}$ \\
Pelt/skin & $75.33^{\mathrm{a}}$ & $73.03^{\mathrm{a}}$ & $52.60^{\mathrm{b}}$ & $48.77^{\mathrm{c}}$ & 4.48 & $*$ \\
Head weight & 53.87 & 58.50 & 56.93 & 56.97 & 2.18 & $\mathrm{NS}$ \\
Tail weight & 2.63 & 2.83 & 2.17 & 2.20 & 0.12 & $\mathrm{NS}$ \\
Fore leg & 4.00 & 4.73 & 3.87 & 3.80 & 0.24 & $\mathrm{NS}$ \\
Hind leg & $9.13^{\mathrm{a}}$ & $8.73^{\mathrm{b}}$ & $8.13^{\mathrm{c}}$ & $7.73^{\mathrm{c}}$ & 0.65 & $*$ \\
\hline
\end{tabular}

$\overline{a b c}=$ means within the same row bearing different superscript differ significantly $(p<0.05) \quad$ NS $=$ not significant difference $(\mathrm{P}>0.05) *=$ significant $(\mathrm{P}<0.05) \mathrm{SEM}=$ standard error of means. least significant difference (LSD)

Key: $T_{1}=$ Concentrate plus Ammarathus $(100 \mathrm{~g}) ; \mathrm{T}_{2}=$ Concentrate plus Tridax procumbens $(100 \mathrm{~g}) ; \mathrm{T}_{3}=$ Concentrate plus Fig leaves (ficus carpensis) $(100 \mathrm{~g}) ; \mathrm{T}_{4}=$ Concentrate plus Water Melon Waste $(100 \mathrm{~g})$

\section{Conclusion}

The forages assessed in this study are cheaply available in all parts of the country and can be successfully used to supplement rabbits diet up to $100 \mathrm{~g}$ without any side effect on carcass characteristics of growing rabbits.

\section{References}

Abu, O. A., Onifade, A. A., Abanikanda, O. T. F. and Obiyan, R. I. 2008. Status and Promotional Strategy for Rabbit Production in Nigeria. In proceedings of $9^{\text {th }}$ World Rabbit Congress Verona, Italy June $10^{\text {th }}$ - 
$13^{t h}, 2008 . p p 1499$ -

1503 http: //worldrabbitscience.com/WRSA-proceedings/ congress-2008verona/Verona$\begin{array}{lllll}2 & 0 & 0 & 8\end{array}$ htm \#managementAccessed $8^{\text {th }}$ janu ary 2012

Adama, T. Z., Ogunbajo, S. A. and Mambo, M. 2007. Feed Intake, Growth Performance and Nutrient Digestibility of Broiler Chicks Fed Diets Containing Varying Levels of Sorghum Dried Brewers' Grains. International Journal of Poultry Science, 6(8), 592-595

Adesope, O. M. 2000. Notes on Acceptance of Duck as Table Meat among Inhabitants of Selected Communities in Niger Delta Zone Ni. Livestock res. Rur, Dev. 23:344-360

Aduku, A. O., Okoh, P. N., Njoku, A. A., Aganga, J. I. and Dim, N. I. 1986. Evaluation of cowpea, Vigna unguiculata and Peanut Arachis hypogeal haulms of feed stuff for weaning rabbits in tropical environment (Nigeria). Journal of Applied Rabbits Research. 9(4), 178-180.

Aduku, A. O. and Olukosi, R. D. 1990. Rabbits Management in Tropics. Living Book Series G.U Publications Abuja Niger Pp1-2

Awosanya, B. 1989. Carcass characteristics of rabbit fed maize replaced with palm oil sludge. Unpunlished Ph.D thesis, Department of Animal Science, University of Ibadan, Oyo State, Nigeria

Biya, A. J., Kannan, A., Murgan, M. and Anil, K. K. 2003. Effect of different feeding system on the carcass characteristics of Newzealand White rabbit.
Department of livestock production Management. College of Veterinary and Animal Sciences, Mannuthy, Thrissur, Kerela. Royal, UK: CAB Editors.

Cheeke, P. R. 1994. Nutrition and nutritional diseases. In;Manning, P. J ., Ringler,D. H. and Newcomer, C.E (Ed). The biology of the laboratory rabbit, $2^{\text {nd }}$ edition. Academic Press, New York.

Duncan, D. R. 1955. Multiple Range and Multiple F-Test. Biometric, 11:142

Esiegwu, A. C., Enyenihi, G. O., Okolo, I. C. and Udedibie, A. B. I. 2013. Organ reaction of laying hens to dietary intake of Garcina kola seed meal. Inter journal of Agric rural Dev. 16:1580-1587

FAO 2006. Food and Agriculture Organization of United Nations Bulleting of Statistics. The MerkVetnary Manual, 9th edition, Merk and co. inc. USA pp. 138139.

Gidenne, T. 1992. Effects of dune reduction de la teneuren fibres alimentaries sur le transit digestif $\mathrm{du}$ lapin. Comparaison et $\mathrm{v}$ a $1 \mathrm{id}$ a $\mathrm{t}$ i o $\mathrm{n}$ d e $\mathrm{mode}$ AnimalZootech, 40, 73-84

Muriu, J. I., Njoko, E. N. M., Tuitoek, J. N. and Nanua, J. N. 2002. Evaluation of sorghum (sorghum bicolor) as replacement of maize in diet of growing rabbit (Oryctolagus cunniculus). Asia Australiisian. Journal of Animal Science. 15:565-569.

Naadam, J., Padi, P., Bigol, R. M. and Mensah, K. 2012. Use of StylosanthesHamata and SidaAcuta as Sole Feeds for Rabbit, (Orytolagus cuniculus). Unline Journal of Animal and Feed 


\section{Carcass characteristics of rabbits fed different forages as supplement}

Research Vol. 2 issue 2.182-188.

NRC, 1981. National Research Council. Nutrient Requirement of domestic animals. No.9 Nutrients Requirement of Rabbits Washington D.C.

Odunsi, A. A. 2003. Assessment of Lablab (lablab purpureu) leaf meal as a feed ingredient and yolk colouring agent in the diet of layer. International Journal of Poultry Science, 2(1), 71-74

Usman, H. I. 2011. Effect of time of intercropping soy beans on weed suppression and performance of upland rice in southern guinea savanna of Nigeria. PhD thesis, Department of crop production. Federal University of Technology Minna,.Niger State.
Taiwo, V. O., Afolabi, O. O. and Adegbuji, A. O. 2014 . Effect of ThevetiePeruviana Seed Cake Based Diet on Growth, Hematology and Tissue of Rabbit. Tropical Sub tropical Agroecosystem 4:7-14

Taylor, M. L., Hartnell, G. F., Riordan, S. $\mathbf{G}$., $\mathbf{N}$ e m e t h , M . A ., Karunanandaa, K., Geoge, B. and Astwood, J. D. 2003. Comparison of broiler performance when fed diets containing grain from YieldGard (MON810), YieldGard $x$ Roundup Ready (GA21) Nontransgenic control, or commercial corn. Poultry Science.2003 (82); 823-830.

Received: $12^{\text {th }}$ May, 2019

Accepted: $19^{\text {th }}$ December, 2019 